\title{
Biological ice-core analysis of Sofiyskiy glacier in the Russian Altai
}

\author{
J. UETAKE, ${ }^{1}$ S. KOHSHIMA, ${ }^{1}$ F. NAKAZAWA,${ }^{2}$ K. SUZUKI, ${ }^{3}$ M. KOHNO,${ }^{4}$ T. KAMEDA, ${ }^{5}$ \\ S. ARKHIPOV, ${ }^{6}$ Y. FUJII ${ }^{4}$ \\ ${ }^{1}$ Graduate School of Bioscience and Biotechnology, Tokyo Institute of Technology, Ookayama 2-12-1, Meguro-ku, \\ Tokyo 152-8551, Japan \\ E-mail: juetake@bio.titech.ac.jp. \\ ${ }^{2}$ Graduate School of Environmental Studies, clo Hydrospheric-Atmospheric Research Center, Nagoya University, \\ Nagoya 464-8601, Japan \\ ${ }^{3}$ Department of Environmental Sciences, Faculty of Science, Shinshu University, Asahi 3-1-1, Matsumoto 390-8621, Japan \\ ${ }^{4}$ National Institute of Polar Research, Kaga, Itabashi-ku, Tokyo 173-8515, Japan \\ ${ }^{5}$ Kitami Institute of Technology, Koen-cho 165, Kitami 090-8507, Japan \\ ${ }^{6}$ Institute of Geography, Russian Academy of Sciences, 23 Staromonetny Street, 109017 Moscow, Russia
}

\begin{abstract}
We examined microorganisms and pollen in a pit $(4.5 \mathrm{~m}$ deep) and a shallow ice core (25.01 $\mathrm{m}$ long) from Sofiyskiy glacier in the Altai mountains of Russia for potential use in dating ice cores from a mid-latitude glacier. The ice-core and pit samples contained various green algae, cyanobacteria, bacteria, fungi and pollen. In the vertical profiles of the pit, algal biomass peaks corresponded to high $\delta^{18} \mathrm{O}$ layers and Pinaceae pollen peaks, suggesting that these algae grew during the melt season. In contrast, the layer with the lowest $\delta^{18} O$ contained almost no algal cells. Major peaks of the cyanobacteria, bacteria and a fungus roughly corresponded to those of the algae. However, seasonal changes in these microorganisms became indistinct deeper in the core, as did the seasonal variation in $\delta^{18} \mathrm{O}$ and major ions, most likely due to heavy meltwater percolation and/or postdepositional decomposition. In contrast, clear seasonal cycles were evident in the algal biomass and pollen in snow samples. Assuming that the peaks of the snow algae and Pinaceae pollen marked summer layers and that the layers with almost no snow algae represented the winter layers, we estimated that the ice core contained 16 annual layers (1985-2001). The mean annual mass balance for the period was estimated to be $1.01 \mathrm{~m}$ w.e. The value agreed well with those estimated from stake measurements, indicating that snow algae and pollen could provide reliable boundary markers of annual layers in the ice cores of this region.
\end{abstract}

\section{INTRODUCTION}

Recently, glaciers in various parts of the world have been reported to be retreating, probably as a result of global warming (Oerlemans, 2005). Especially in central Asia, glaciers have experienced rapid shrinking, and current trends suggest that this wastage will accelerate (Dyurgerov and others, 2002). Therefore, ice-core studies in central Asia are important for understanding the response of glaciers to the recent warming in this region. However, in analyses of ice cores from lower-latitude regions such as central Asia, it can be difficult to use seasonal changes in $\delta^{18} \mathrm{O}$ and chemical concentrations for ice-core dating because initial patterns of stable isotopes and chemical ions are often disturbed by heavy meltwater percolation in the glacial strata (lizuka and others, 2000). To minimize melt distortion of $\delta^{18} \mathrm{O}$ and chemical concentrations, samples should be collected at high elevations (Thompson and others, 1989, 1995, 2000) where summer melting is very low; however, drilling operations are more difficult and dangerous at such sites, so new dating methods that are applicable to ice cores from lower latitudes and lower-altitude glaciers must be developed.

In a Himalayan glacier in Nepal, Yoshimura and others (2000) suggested that snow algae growing on the glacier surface during the melt season are incorporated into the glacial strata in autumn and serve as useful boundary markers of annual layers for dating ice cores from this region. These algae growing in the snow and ice support specialized biotic communities on the glacier, including cold-tolerant insects and copepods, as reported in Himalayan (Kohshima 1984, 1987; Yoshimura and others, 1997) and Patagonian glaciers (Kohshima, 1985; Takeuchi and Kohshima, 2004). Kohshima and others (2002) noted that these glacier microorganisms preserved in ice cores could be reliable annual markers for ice-core dating and provide important signals for past environmental conditions, especially for temperate glaciers, because biotic activity on glaciers increases with glacial melting. However, they also reported that in the deeper parts of the ice core, quantification and species identification of snow algae becomes difficult due to autolysis or bacterial decomposition of the algal cells. Nakazawa and others (2004) focused on pollen that was seasonally dispersed on glaciers and showed that pollen found in ice cores from a glacier in the Altai mountains in Russia could be used to determine annual layers. They cited the following three advantages of pollen dating: (1) pollen is well protected from decay by an outer shell of sporopollenin; (2) the large grain-size $(10-150 \mu \mathrm{m})$ helps the pollen to remain at its original depth despite meltwater incursion; and (3) this method can also distinguish seasonal boundaries by using different pollen species. However, to improve the reliability of ice-core dating, it would be beneficial to use multiple information sources, such as pollen and snow algae. In addition, ice-core analysis using microorganisms growing on the glacier (e.g. snow algae) may provide information on past environmental 
conditions, including temperature and snow accumulation during the growth season, both factors that affect the growth of these organisms (Yoshimura and others, 2000; Kohshima and others, 2002).

Thus, ice-core analyses using microorganisms should be further developed. However, studies on the microorganisms found in ice cores from mid-latitude glaciers remain very limited. Such studies have only been conducted on Himalayan and Patagonian glaciers (Yoshimura and others, 2000; Shiraiwa and others, 2002), and only snow algae were examined in these studies. Many other kinds of organisms, including cyanobacteria, bacteria and fungi, have been reported from glaciers in various parts of the world (Kol and Peterson, 1976; Takeuchi, 2001; Segawa and others, 2005). To develop an ice-core analysis technique using microorganisms, these microorganisms should be studied in ice cores from different parts of the world in order to understand the relationship between their growth and environmental conditions and their post-depositional changes.

For this study, we examined microorganisms and pollen in a $4.5 \mathrm{~m}$ pit and a $25.01 \mathrm{~m}$ ice core from Sofiyskiy glacier in the Russian Altai for potential use in ice-core analyses of this region. We analyzed not only snow algae and pollen but also cyanobacteria, bacteria and fungi together with $\delta^{18} \mathrm{O}$ and chemical ions. In addition, we estimated the annual mass balance from the results of the ice-core dating using snow algae and pollen.

\section{METHODS}

\section{Area description}

The research was conducted at Sofiyskiy glacier in the south Chuyskiy range of the Russian Altai (Fig. 1). This glacier flows northeastward for about $7 \mathrm{~km}$, covering a total area of about $16 \mathrm{~km}^{2}$. The equilibrium-line altitude estimated from stake measurements in summer is around 3179 ma.s.l. (Pattyn and others, 2003). The extreme continentality of the Altai gives rise to aridity and a large diurnal and seasonal temperature range. Furthermore, because of the coincidence of the accumulation and ablation seasons in summer, we can characterize the Altai glaciers as summer-accumulation glaciers (De Smedt and Pattyn, 2003; Pattyn and others, 2003; Fujita and others, 2004). Glaciological observations, ice-core drilling and snow-pit sampling were conducted on the accumulation area of this glacier $\left(49^{\circ} 47^{\prime} 10^{\prime \prime} \mathrm{N}, 87^{\circ} 43^{\prime} 48^{\prime \prime} \mathrm{E} ; 3435 \mathrm{~m}\right.$ a.s.I.) from 6 to 17 July 2001. A $25.01 \mathrm{~m}$ deep ice core was recovered with a hand drill, and a $4.5 \mathrm{~m}$ deep pit was excavated about $50 \mathrm{~m}$ northwest of the drill site. The ice thickness near the drill site was estimated to be $>200 \mathrm{~m}$ (Pattyn and others, 2003).

At the drill site, some surface melting and accumulation were observed during the summer season, and the firn temperature often rose to $0^{\circ} \mathrm{C}$ (Fujii and others, 2002). The upper $18.25 \mathrm{~m}$ of the core consisted of firn with melt features (ice layers of refrozen meltwater) that also indicated meltwater percolation at the drill site during summer. The lower part of the core below $18.25 \mathrm{~m}$ consisted of ice, so possible effects of meltwater percolation could reach down to $18.25 \mathrm{~m}$ depth. Further details of the physical properties of the ice core are provided by Kameda and others (2004). The ice-core drilling operation is described in detail by Fujii and others (2000, 2002).

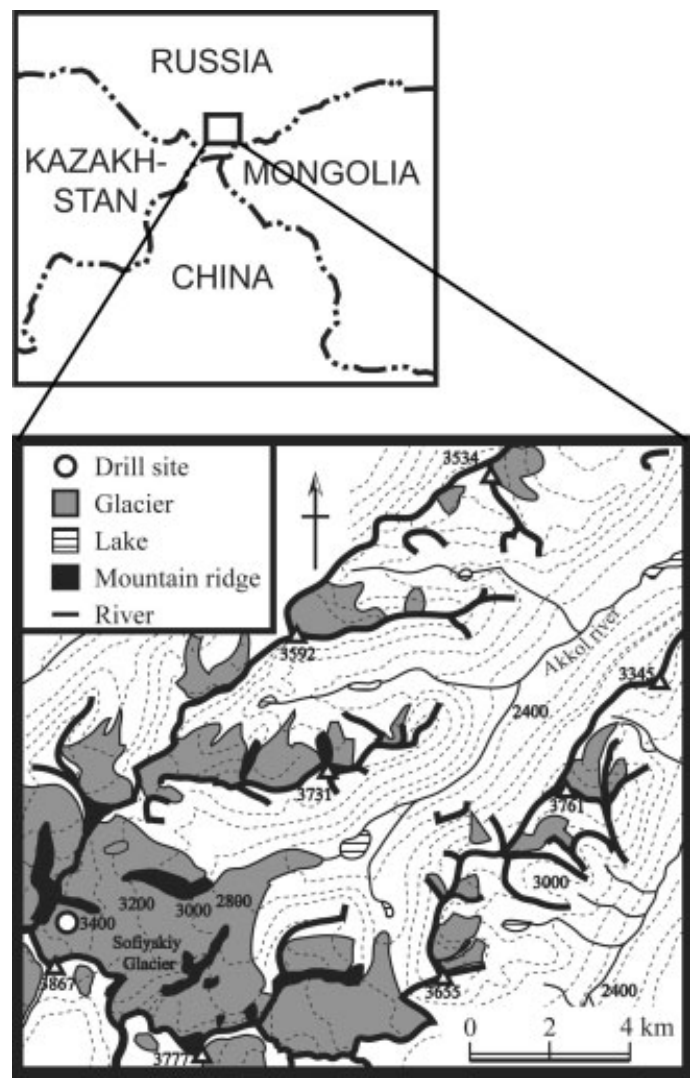

Fig. 1. Location of Sofiyskiy glacier in the Russian Altai, and the sampling sites on the glacier.

\section{Sample processing}

Sample processing of the pit and the ice core was conducted in a $2 \mathrm{~m}$ deep snow trench near the drilling site. Pit samples were obtained every $10 \mathrm{~cm}$ using a sterilized stainless-steel scoop. The core samples were cut with pre-cleaned ceramic knives at intervals of about $20 \mathrm{~cm}$, and $1 \mathrm{~cm}$ of the core surface was scraped off to eliminate contamination. The samples were packed into sterilized plastic bags, and, after melting, all samples were dispensed into clean plastic bottles and fixed in 3\% formalin solution, before being shipped at room temperature to the Tokyo Institute of Technology. To identify species, some samples were fixed in $10 \%$ glutaraldehyde or Lugol's solution and shipped to the laboratory at cold temperatures $\left(0-5^{\circ} \mathrm{C}\right)$. We analyzed all samples from the pit and the ice core for microorganisms, pollen concentrations, oxygen isotope ratios $\left(\delta^{18} \mathrm{O}\right)$ and chemical concentrations.

\section{Sample analysis}

For the analysis of microorganisms and pollen, all $10 \mathrm{~mL}$ samples were filtered through hydrophilic polytetrafluoroethylene (PTFE) membrane filters (JHWP01300: $0.2 \mu \mathrm{m}$ pore size, $13 \mathrm{~mm}$ diameter; Millipore, USA), and cells of microorganisms and pollen grains on the filters were counted under a fluorescent microscope (Nikon: E-600). For the bacterial analysis, the samples filtered on the membrane filters were dyed by adding a small amount of SYBR GREEN I and an antifade mounting solution (50\% glycerol, 50\% phosphate-buffered saline (PBS), $0.1 \%$ $p$-phenylenediamine). To enumerate pollen grains and algal cells larger than $20 \mu \mathrm{m}$, we counted all algal cells and pollen on the filter. For algae smaller than $20 \mu \mathrm{m}$, cyanobacteria 
Table 1. Snow microorganisms and pollen from pit and ice-core samples. Density is the maximum value in the pit samples

\begin{tabular}{|c|c|c|c|}
\hline Species & Figure & Size and morphology & $\begin{array}{c}\text { Density } \\
\text { cells } \mathrm{mL}^{-1}\end{array}$ \\
\hline
\end{tabular}

\begin{tabular}{|c|c|c|c|}
\hline \multicolumn{4}{|c|}{ Chlorophyta (green algae) } \\
\hline $\begin{array}{l}\text { Unknown alga } \\
\text { sp. } 1\end{array}$ & $2 \mathrm{a}$ & $\begin{array}{l}\text { Cells spherical, colorless, } \\
20-30 \mu \mathrm{m} \text { in diameter with } \\
\text { warty envelope }\end{array}$ & 4.4 \\
\hline $\begin{array}{l}\text { Unknown alga } \\
\text { sp. } 2\end{array}$ & $2 b$ & $\begin{array}{l}\text { Cells oval, } 2-3 \text { times longer } \\
\text { than the width, colorless, } \\
12-15 \mu \mathrm{m} \text { long, } 4-6 \mu \mathrm{m} \text { wide }\end{array}$ & $3.3 \times 10^{2}$ \\
\hline $\begin{array}{l}\text { Unknown alga } \\
\text { sp. } 3\end{array}$ & $2 \mathrm{c}$ & $\begin{array}{l}\text { Cells spherical, colorless, } \\
20-30 \mu \mathrm{m} \text { in diameter with thick } \\
\text { envelope }\end{array}$ & 11 \\
\hline $\begin{array}{l}\text { Unknown alga } \\
\text { sp. } 4\end{array}$ & $2 d$ & $\begin{array}{l}\text { Cells spherical, colorless, } \\
20-30 \mu \mathrm{m} \text { in diameter with thin } \\
\text { envelope; no organelles were } \\
\text { observed }\end{array}$ & 1 \\
\hline $\begin{array}{l}\text { Unknown alga } \\
\text { sp. } 5\end{array}$ & $2 \mathrm{e}$ & $\begin{array}{l}\text { Cells spherical, colorless, } \\
5-12.5 \mu \mathrm{m} \text { in diameter with } \\
\text { thin envelope; no organelles were } \\
\text { observed }\end{array}$ & $1.1 \times 10^{3}$ \\
\hline \multicolumn{4}{|l|}{ Cyanobacteria } \\
\hline $\begin{array}{l}\text { Coccoid } \\
\text { cyanobacterium } \\
\text { Bacteria }\end{array}$ & $2 f$ & $\begin{array}{l}\text { Cells round or oval, } 3 \mu \mathrm{m} \text { in } \\
\text { diameter }\end{array}$ & $1.7 \times 10^{4}$ \\
\hline Coccoid bacteria & $2 \mathrm{~g}$ & $\begin{array}{l}\text { Cells round or oval, } 1 \mu \mathrm{m} \text { in } \\
\text { diameter }\end{array}$ & $1 \times 10^{5}$ \\
\hline \multicolumn{4}{|l|}{ Fungi } \\
\hline $\begin{array}{l}\text { Chionaster } \\
\text { bicornis }\end{array}$ & $2 \mathrm{~h}$ & $\begin{array}{l}\text { Cells with two long, pointed } \\
\text { horns, } 5 \mu \mathrm{m} \text { wide and } 40-60 \mu \mathrm{m} \\
\text { long }\end{array}$ & 35 \\
\hline $\begin{array}{l}\text { Chionaster } \\
\text { nivalis }\end{array}$ & $2 \mathrm{i}$ & $\begin{array}{l}\text { Cells with several star-like shapes } \\
\text { with thin envelope and } 50-60 \mu \mathrm{m} \\
\text { long }\end{array}$ & 3.4 \\
\hline \multicolumn{4}{|l|}{ Pollen } \\
\hline Pinaceae trees & $2 \mathrm{j}$ & $\begin{array}{l}\text { Grains vesiculate, disaccate, } \\
\text { usually with a constriction } \\
\text { between the body and bladders, } \\
50-130 \mu \mathrm{m} \text { in diameter }\end{array}$ & 35 \\
\hline Artemisia weeds & $2 \mathrm{k}$ & $\begin{array}{l}\text { Grains tricolporate, } 20-25 \mu \mathrm{m} \text { in } \\
\text { diameter }\end{array}$ & 5 \\
\hline
\end{tabular}

and bacteria, we estimated the total cell number on the filter by counting the cells along a line crossing the filter center $(0.25 \times 13 \mathrm{~mm}$ for algae and cyanobacteria, $0.1 \times 6.5 \mathrm{~mm}$ for bacteria, one to three lines).

Algal biomass in the sample was represented by the total algal volume $\left(\mu \mathrm{m}^{3} \mathrm{~mL}^{-1}\right)$, which was determined by quantifying the number of the cells and their volume under a microscope (Yoshimura and others, 1997, 2000; Takeuchi and Kohshima, 2004). Algal density was expressed as cells $\mathrm{mL}^{-1}$, and cell volume was estimated based on its dimensions. Mean cell volume was estimated by measuring the size of 50-100 cells for each species. Total algal biomass was determined by multiplying mean cell volume $\left(\mu \mathrm{m}^{3}\right)$ by algal density (cells $\mathrm{mL}^{-1}$ ). Oxygen isotope and major-ion concentrations $\left(\mathrm{Na}^{+}, \mathrm{Ca}^{2+}, \mathrm{K}^{+}, \mathrm{NH}_{4}{ }^{+}, \mathrm{Mg}^{2+}, \mathrm{NO}_{3}{ }^{-}, \mathrm{SO}_{4}{ }^{2-}\right.$, $\mathrm{Cl}^{-}$) were measured with a stable-isotope mass spectrometer (MAT Delta-E, Finnigan MAT, Germany) and a DX500 ion chromatograph (Dionex Corp., USA), respectively, at the National Institute of Polar Research, Tokyo, Japan (Kameda and others, 2003). Pollen density was analyzed at Nagoya University (Nakazawa and others, 2004).

\section{RESULTS AND DISCUSSION}

\section{Microorganisms and pollen observed in the pit and ice-core samples}

In the pit and ice-core samples, five unidentified green algae, a coccoid cyanobacterium, a coccoid bacterium, two species of fungus and two types of pollen were observed (Table 1; Fig. 2).

\section{Green algae}

The green algae found in the samples, especially unknown alga spp. 2 and 5, were assumed to be snow algae growing on the glacier. Maximum cell densities in the pit exceeded $1 \times 10^{2}$ cells $\mathrm{mL}^{-1}$ for unknown sp. 2 and $1 \times 10^{3}$ cells $\mathrm{mL}^{-1}$ for unknown sp. 5 . These values are similar to those reported from surface snow of perennial snowpatches in the Sierra Nevada, USA, during mid-summer, when snow-algal blooms often form red snow (Thomas and Duval, 1995). Although their cell density was not as high, other green algal species also appear to grow on the glacier, because it is highly unlikely that these algal cells were transported by wind. The observed cells appeared too fragile to tolerate desiccation during long periods of air transportation. In addition, there are no lakes in this area that would be potential sources of these green algae. How the snow algae reach the snow surface of the glacier and begin to grow there remains unclear. Müller and others (1998, 2001) studied snow-algal blooms on Spitsbergen, Svalbard, and suggested that algal growth on perennial snowpatches is initiated by the deposition of airborne resting spores, which are tolerant of desiccation and strong radiation during longdistance air transport.

\section{Cyanobacteria and bacteria}

Cyanobacteria and bacteria found in the samples were assumed to grow on the glacier because their maximum density in the pit was very high, i.e. over $1 \times 10^{4}$ and $1 \times 10^{5}$ cells $\mathrm{mL}^{-1}$, respectively. The maximum cell densities of the bacteria in the samples were similar to those reported from surface snow in perennial snowpatches during mid-summer (Thomas and Duval, 1995).

\section{Fungi}

Both fungi found in the samples, Chionaster bicornis and C. nivalis, have been reported from snow environments in various parts of the world (Kol, 1968) and are presumed to grow in snow and ice. Thus, these fungi were also assumed to grow on the glacier, although their maximum densities in the pit were not high (35 and 3.4 cells mL ${ }^{-1}$, respectively).

\section{Pollen}

Pollen of Pinaceae trees and Artemisia weeds were found in the samples. According to a study on plants in the Russian Altai (Luchik, 1970), flowering of Pinaceae begins in May. Luchik (1970) did not report on the flowering season of Artemisia in this region, although Artemisia typically flowers in early autumn. Thus, we assumed that the flowering season of this weed near the glacier occurred in early autumn (late August and September). Maximum densities of Pinaceae and Artemisia pollen in the pit are 35 and 5 grains $\mathrm{mL}^{-1}$, respectively. 

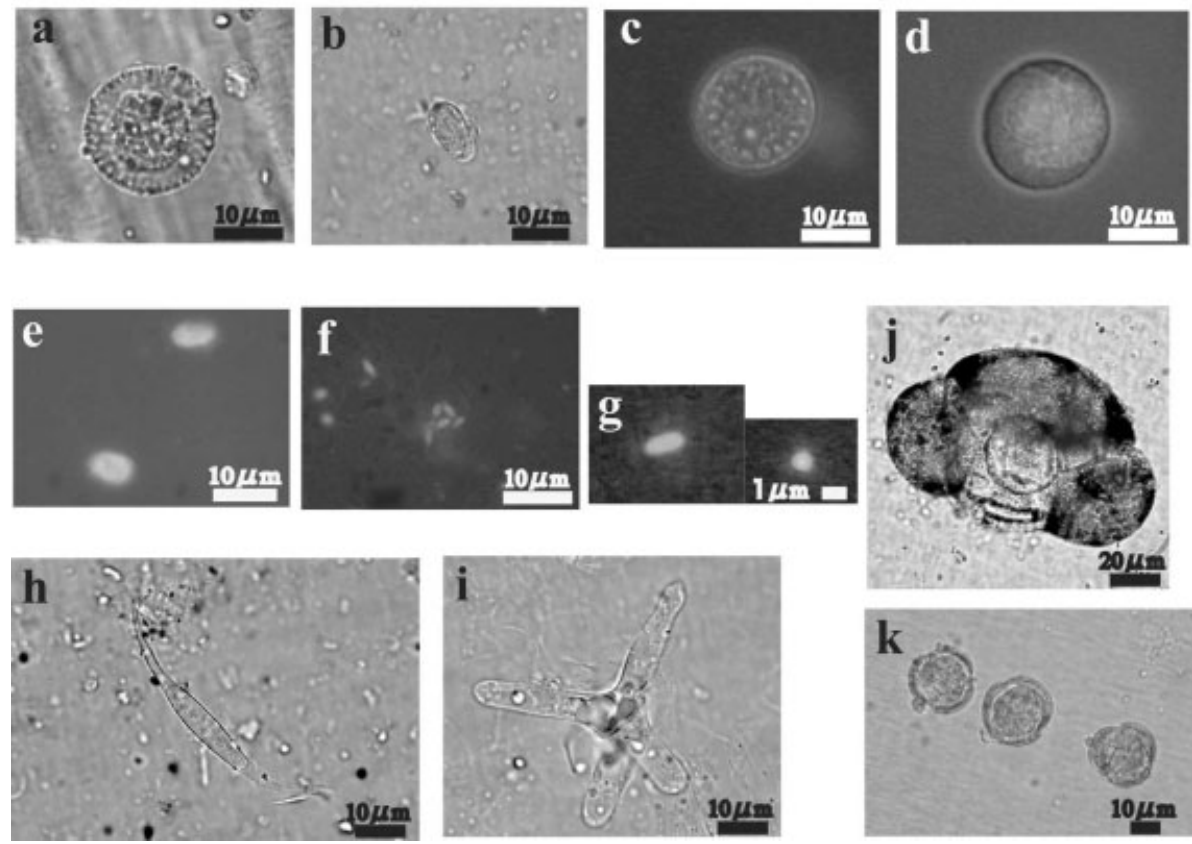

Fig. 2. Snow algae and pollen observed in the pit and ice-core samples from Sofiyskiy glacier: (a) unidentified alga sp. 1; (b) unidentified alga sp. 2; (c) unidentified alga sp. 3; (d) unidentified alga sp. 4; (e) unidentified alga sp. 5; (f) unidentified cyanobacterium; (g) unidentified bacterium; (h) Chionaster bicornis; (i) C. nivalis; (j) Pinaceae pollen; and (k) Artemisia pollen. Pictures (a), (d), (h), (i), (j) and (k) were taken under a light microscope; pictures (b), (c), (e), (f) and (g) were taken through ultraviolet excitation with a B filter under a fluorescence microscope.

\section{Pit analysis}

\section{Snow algae and pollen}

The vertical profiles of algal biomass, $\delta^{18} \mathrm{O}, \mathrm{Na}^{+}$ions and pollen in the $4.5 \mathrm{~m}$ pit are shown in Figure 3. The vertical $\delta^{18} \mathrm{O}$ profile showed three peaks, although seasonal changes were indistinct in the deeper sections, probably due to heavy meltwater percolation. Records of major-ion concentrations show that the peaks disappear rapidly (Kameda and others, 2003; e.g. $\mathrm{Na}^{+}$concentrations are shown in Fig. 3c). The $\mathrm{Na}^{+}$peaks deeper in the pit are unclear, although a distinct peak is evident at the surface to $0.10 \mathrm{~m}$ depth. Thus, chemical ion species from deeper parts of a core cannot be used.
Snow chemistry can be affected by biological activity, but no clear relationship was observed between the snowalgal density and concentration of $\mathrm{Na}^{+}$and other ions, suggesting that the initial patterns of chemical ions were mainly disturbed by meltwater percolation. In the profile of algal biomass, we observed three layers with high algal biomass (0-0.7, 1.4-2.7, 3.9-4.5 m; shaded layers in Fig. 3) and two layers with low algal biomass. These three highbiomass layers correspond to the peaks of $\delta^{18} \mathrm{O}$, suggesting that these layers were formed during warm periods. The pollen profiles also showed very distinct peaks. Pinaceae peaks occurred at depths of $0.1-0.2,2.4-2.5$ and $4.3-4.4 \mathrm{~m}$, while Artemisia peaks were about $0.2-0.3 \mathrm{~cm}$ above the Pinaceae peaks (Fig. 3e). These pollen peaks appear to

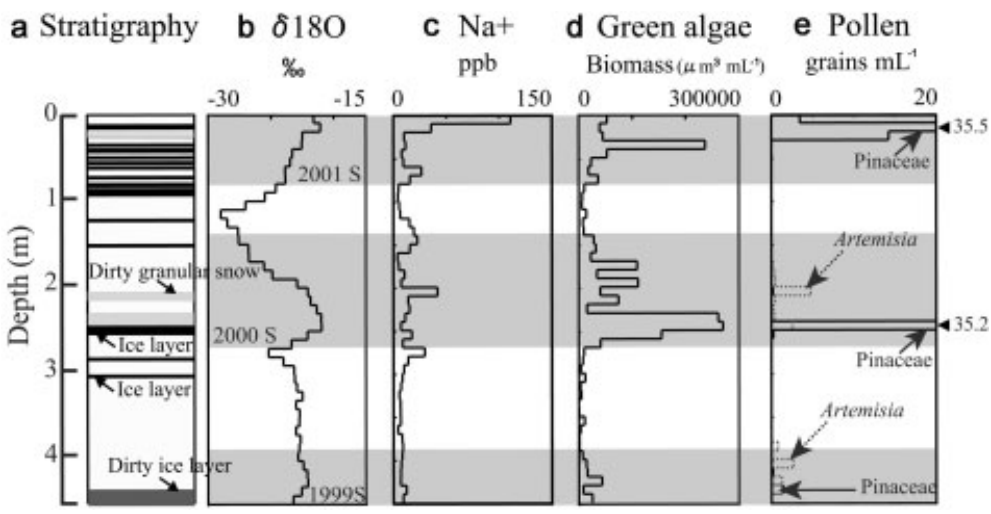

Fig. 3. Vertical profiles of the $4.5 \mathrm{~m}$ pit on Sofiyskiy glacier: (a) physical stratigraphy; (b) oxygen isotope; (c) sodium ion; (d) algal biomass; and (e) pollen (Pinaceae, Artemisia). The gray shaded area indicates the algal growth period (early summer-early autumn) estimated from algal peaks. The gray areas are drawn based on the profile of algal biomass, taking into consideration the effect of downward transportation of some algal cells by meltwater percolation. We assume that the small algal biomass peaks among the distinct, larger growth-season peaks are the result of cell transportation by meltwater. 


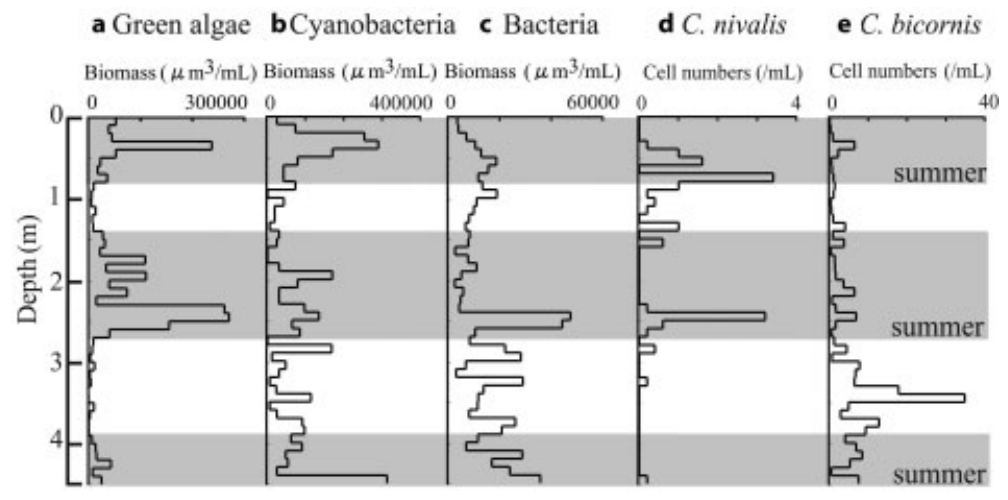

Fig. 4. Vertical profiles of snow microorganisms in the $4.5 \mathrm{~m}$ pit: (a) snow algae; (b) cyanobacteria; (c) bacteria; (d) Chionaster nivalis; and (e) C. bicornis. The gray shaded area shows the layer of the algal-growth period (early summer-early autumn) estimated from algal biomass.

correspond with the algal layers, which suggests that the algal layers were formed during summer because, in general, pollen of Pinaceae are scattered from late spring to early summer, and those of Artemisia are dispersed in early autumn (Nakazawa and others, 2004).

These results suggest that the algal layers were formed during melt seasons by algal growth on the glacier, and that layers with very low algal biomass were formed during cold seasons when algae could not grow without meltwater, which is essential for their growth (Yoshimura and others, 2000). In particular, two distinct algal peaks (0.4 and 2.3$2.5 \mathrm{~m}$ ) were very close to the peaks of Pinaceae pollen and the $\delta^{18} \mathrm{O}$ peaks, suggesting that the main algal bloom occurred during mid-summer. In contrast, small algal peaks $(1.7-2.2 \mathrm{~m})$ above the distinct algal peak $(2.3-2.5 \mathrm{~m})$ and another small peak (4-4.5 m) corresponded to peaks of Artemisia pollen, suggesting that these peaks were formed from summer to autumn. These results suggest that several algal peaks were formed during the melt season at this site.

In contrast, Yoshimura and others (2000) reported that only one algal peak was formed during summer in a Himalayan glacier. This was probably due to the frequent snowfall during the algal growth period at this site. As snow algae require not only meltwater but also solar radiation for photosynthesis, they can grow only near the surface. In general, light intensity in the snow decreases exponentially with depth (Richardson and Salisbury, 1977). Only $1 \%$ of the surface light intensity penetrates to $18 \mathrm{~cm}$ depth in dry new snow and to a maximum depth of $110 \mathrm{~cm}$ in wet and dense firn (Curl and others, 1972). Yoshimura and others (2000) reported that algal growth on a Himalayan glacier stopped after the surface was covered by $35 \mathrm{~cm}$ of snow. Thus, given the frequent snowfall during their growth period, the formation of several peaks of algal biomass in each melt season probably resulted from the episodic burial of surface layers. Buried algae are therefore stored in the glacial strata, and new algal growth restarts near the new surface. Hoham and Duval (2001) suggest a visible bloom of snow algae in seasonal snowfields starts when a small number of flagellated algal cells migrate from the snow-soil interface. Their work suggests that the process begins with the germination of the resting spores that detect weak light penetrating the thinning snow cover in spring. These cells swim in the liquid meltwater surrounding the snow crystals toward the upper part of the snowpack and start to grow near the surface where the light conditions are suitable for photosynthesis. Based on the results of Hoham and Duval
(2001), it is possible that some of the snow algae migrated through the snow strata at our study site. However, snow layers with a high concentration of algal cells in the glacial strata should be formed only near the surface because flagellated cells swimming upward in the snowpack also stop and start to grow near the surface where light intensity is high enough for their growth.

Large algal peaks at our study site were probably formed during mid-summer by rapid algal growth and condensation of algal cells, which grew in early summer and were stored in the glacial strata, on the surface as surface melting proceeded. Small algal peaks were probably formed from summer to autumn when the episodic burial of surface layers by snowfall started again as temperature decreased. Meteorological observations at the drill site from 15 to 24 July 2000 and from 7 to 17 July 2001 showed such surface level changed by melting and snowfall (Fujii and others, 2002; Suzuki and others, 2002). The profiles of $\delta^{18} \mathrm{O}$, algal biomass and pollen suggest that the $4.5 \mathrm{~m}$ pit included two full years of snow accumulation (summer 1999-summer 2001). According to the distinct peaks of the snow-algal biomass and Pinaceae pollen, the net balance during summer 2000-summer 2001 and summer 1999-summer 2000 was 1.9 and $1.7 \mathrm{~m}$ in snow depth, respectively. These values agree with actual snow accumulation $(1.78 \mathrm{~m})$ estimated by fixed stake measurements from July 2000 to July 2001. These results suggest that snow algae and pollen are good seasonal markers for ice-core analysis of this region.

\section{Other microorganisms}

Cyanobacteria require solar radiation and meltwater for photosynthesis. Therefore, they may bloom during summer along with the snow algae. However, seasonal changes in the profile of cyanobacterial biomass were not as clear as those of snow algae (Fig. 4b). Although some distinct peaks $(0.3-0.4,1.9-2.7$ and $4.4-4.5 \mathrm{~m})$ corresponded to algal peaks, some peaks were observed even in the winter layers $(0.9-1.4$ and $2.7-3.5 \mathrm{~m})$ estimated from the profiles of $\delta^{18} \mathrm{O}$, algal biomass and pollen. These peaks in the winter layers may have been formed by downward transport of the cells due to meltwater percolation, because the cells of cyanobacteria are small ( $3 \mu \mathrm{m}$ diameter) and can easily be washed out. The profile of bacterial biomass (Fig. 4c) shows a low and broad peak $(0.5-1 \mathrm{~m})$ in the upper layer and many high peaks in the lower layer below $2.5 \mathrm{~m}$. Numerous peaks in the lower layer are higher than the broad peak $(0.5-1 \mathrm{~m})$ and 


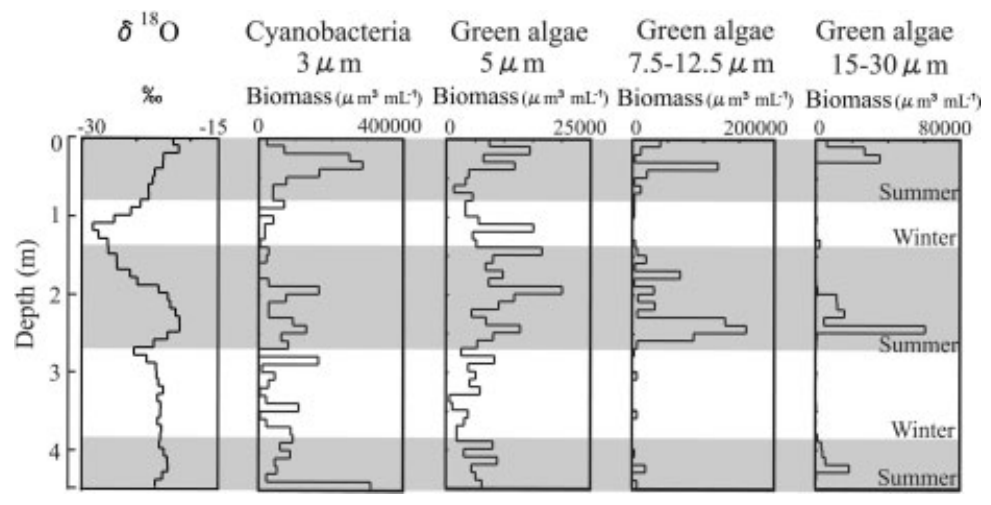

Fig. 5. Vertical profiles of snow microorganisms with various cell sizes in the $4.5 \mathrm{~m}$ pit. Profiles of larger organisms are located on the right.

are evident even in a winter layer (2.7-3.9 m). This suggests that these bacteria grew in the deeper part of the glacial strata after deposition, because bacteria can grow without solar radiation using organic materials transported by meltwater. The broad peak $(0.5-1 \mathrm{~m})$ in the upper layer was located slightly below the algal peak $(0.4 \mathrm{~m})$, and the highest peak (2.4-2.6 m) of the lower layer corresponded to the highest algal peak $(2.3-2.5 \mathrm{~m})$, suggesting that these bacteria grew using organic products of photosynthetic organisms. In the profile of Chionaster nivalis cell numbers, two distinct peaks (0.6-0.7 and 2.4-2.5 m) were evident, and these corresponded to the bacterial peaks (Fig. 4d). This suggests that $C$. nivalis can also grow in the snow utilizing organic products of photosynthetic organisms. In the profile of $C$. bicornis cell numbers, distinct peaks $(3.4-3.5 \mathrm{~m})$ were observed in the lower layers, including a winter layer, but no clear seasonal variation was observed (Fig. 4e). Although the ecology of this species is still unknown, its profile, which was similar to that of bacteria (higher peaks in the lower layer), suggests that this fungus also continues to grow in the deeper parts of the snow.

Difference in meltwater effects depending on cell size Figure 5 shows the vertical profiles of photosynthetic microorganisms with different cell sizes. Profiles of larger organisms are located on the right. Although all photosynthetic microorganisms can grow only near the surface where solar radiation essential for their growth is available, their profiles differ somewhat depending on their cell size. Seasonal changes are clearer in the biomass of larger organisms than in that of smaller organisms. The biomass peaks are broader in smaller organisms (3-5 $\mu \mathrm{m}$ diameter) than in larger organisms $(7.5-30 \mu \mathrm{m}$ diameter) and are distributed more evenly even in the winter layers. This is probably because the effect of washout by meltwater decreases as the particle size of the material being moved increases. This result suggests that small cells $(<5 \mu \mathrm{m})$ are not suitable as seasonal markers in ice-core analyses. Therefore, we used only large snow-algal cells $(7.5-30 \mu \mathrm{m})$ as seasonal markers in our ice-core analysis.

\section{Ice-core analysis}

Figure 6 shows the vertical profiles of $\delta^{18} \mathrm{O}$, algal biomass and Pinaceae pollen in the $25.01 \mathrm{~m}$ ice core. In the snowalgal biomass, only large cells $(7.5-30 \mu \mathrm{m})$ were included to minimize distortion by meltwater. This figure shows that the amplitudes of seasonal cycles in $\delta^{18} \mathrm{O}$ values rapidly decreased with depth, and the cycles generally became indistinct below $5 \mathrm{~m}$ due to meltwater percolation. In contrast, the peaks of snow algae and pollen were well preserved in the ice core. Since several algal peaks can be formed during a melt season at this site, we used a threesample running mean (Fig. 6c) to identify large summer peaks formed in mid-summer by filtering the noise of small peaks formed in autumn and early summer. In the runningmean profile of the snow-algal biomass, we found 17 peaks (summer peaks; black triangles in Fig. 6c). The layers with peaks in the algal biomass profile (black triangles in Fig. 6b) corresponding to the summer peaks in Figure 6c were identified as summer layers (shaded layers in Fig. 6), and the lowest points between two summer layers were identified as

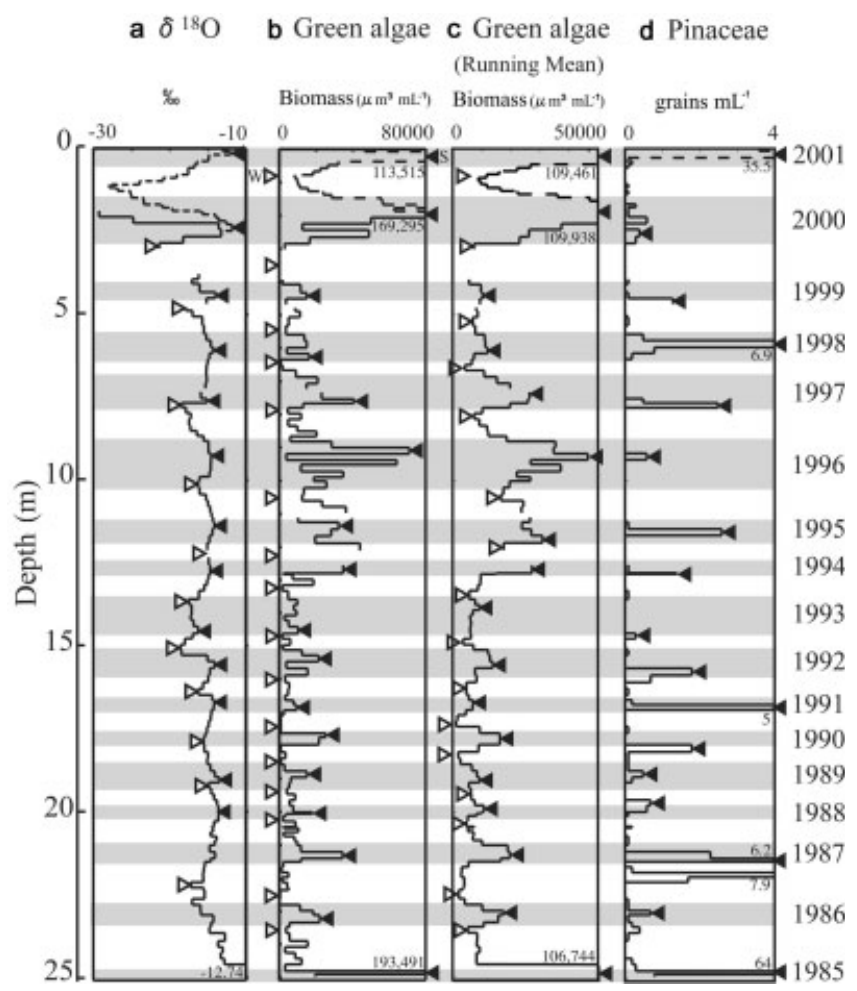

Fig. 6. Vertical profiles of $\delta^{18} \mathrm{O}$, snow algae and pollen in a $25.01 \mathrm{~m}$ ice core from Sofiyskiy glacier: (a) oxygen isotope; (b) algal biomass; (c) algal biomass (running mean); and (d) pollen (Pinaceae). Dashed lines indicate data obtained from the pit samples. The gray shaded area is the layer of the algal-growth period estimated from algal biomass. 


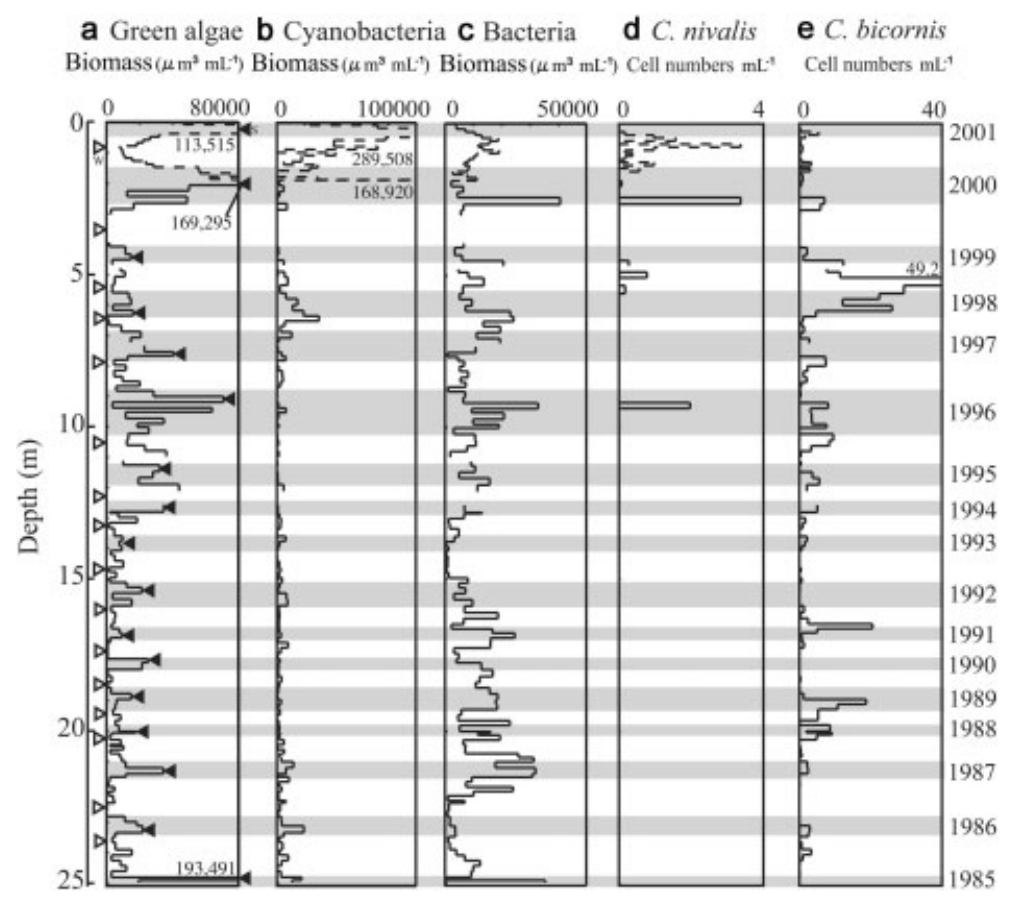

Fig. 7. Vertical profiles of snow microorganisms in a $25.01 \mathrm{~m}$ ice core from Sofiyskiy glacier: (a) snow algae; (b) cyanobacteria; (c) bacteria; (d) Chionaster nivalis; and (e) C. bicornis. Dashed lines indicate data obtained from the pit samples. The gray shaded area indicates the layer of the algal-growth period estimated from algal biomass.

mid-winter layers (white triangles in Fig. $6 \mathrm{~b}$ and c). These summer layers identified by snow algae appear to correspond with the peaks of Pinaceae pollen and $\delta^{18} \mathrm{O}$ (Fig. $6 \mathrm{~d}$ ). All 17 summer layers included the corresponding peaks of Pinaceae pollen, and 13 summer layers had the corresponding $\delta^{18} \mathrm{O}$ peaks, with the association becoming less apparent deeper in the core.

Nakazawa and others (2004) identified annual layers in the upper $18.25 \mathrm{~m}$ of this ice core using a pair of peaks from Pinaceae pollen and Artemisia pollen as a marker for a summer layer. In their analysis, if no Artemisia peak appeared between two Pinaceae peaks, the Pinaceae peaks were assumed to be peaks from the same year, because Pinaceae and Artemisia disperse pollen in different seasons. All 17 summer layers identified by snow algae corresponded to the Pinaceae peaks identified as summer layers by this method (black triangles in Fig. 6d). Thus, we estimated that this $25.01 \mathrm{~m}$ ice core included 17 summer layers from 1985 to 2001. In this ice core, $\delta^{18} \mathrm{O}$ peaks were unclear, especially below $20 \mathrm{~m}$, and more than one peak was formed by snow algae (e.g. 1992 and 1996) and pollen (e.g. 1986 and 1987) due to the frequent burial of the surface by snowfall during the summer. However, we were able to improve the reliability of the ice-core dating by using three different information sources (snow algae, pollen and $\delta^{18} \mathrm{O}$ ), which complemented each other.

Figure $7 \mathrm{~b}-\mathrm{e}$ show the profiles of microorganisms other than snow algae. The profiles of cyanobacteria, bacteria and C. bicornis seemed to be disturbed by meltwater or postdepositional decomposition, although some peaks correspond to the summer layers estimated from snow algae and pollen. Peaks of $C$. nivalis (Fig. 7d) were observed only in the upper part of the ice core above $10 \mathrm{~m}$, suggesting that the profile of this species was disturbed by post-depositional decomposition. Therefore, these organisms are unsuitable as seasonal markers in this ice core, but they have the potential to provide some information about the past environmental conditions on the glacier that affected their growth.

\section{Estimation of the glacier mass balance}

According to the profiles of snow algae, pollen and $\delta^{18} \mathrm{O}$, we estimated that this $25.01 \mathrm{~m}$ ice core included 17 summer layers and contained 16 full years of accumulation between summer 1985 and summer 2001. Since more than one peak of snow algae and pollen can be formed during summer at the study site, we estimated annual layers (winter-winter) assuming that the lowest algal biomass values between two summer layers (identified by snow algae) were winter layers (white triangles in Fig. 6b). The mean annual mass balance from 1985 to 1999 was estimated to be $1.01 \mathrm{~m}$ w.e. (0.58$2.27 \mathrm{~m}$ w.e). This estimation is in good agreement with the mass balance estimated from stake measurements ( $\sim 1.25$ m w.e.; Pattyn and others, 2003). The results of this study indicate that snow algae and pollen could be a useful seasonal marker for ice-core dating in lower-latitude and lower-altitude glaciers where initial patterns of stable isotopes and chemical ions are often disturbed by heavy meltwater percolation. By this method, we will be able to reconstruct past annual mass balance even in lower-latitude and lower-altitude glaciers where signals of stable isotopes and chemical ions are unreliable in ice-core analysis. However, when we apply this method to glaciers from other parts of the world, we should clarify the seasonal pattern of snow algal growth and pollen dispersion in that region by pit analysis based on the difference in the number of algal peaks observed in this and previous studies (e.g. Yoshimura and others, 2000). As shown in this study, even in lower-latitude and lower-altitude glaciers we will be able to clarify seasonal changes in snow algae and pollen by pit analysis using other signals because seasonal changes in stable isotopes and chemical ions tend to remain in the glacial strata near the surface before heavy meltwater percolation. 
To analyze microorganisms in deeper ice cores, new techniques to identify and quantify microorganisms more rapidly and precisely must also be developed.

Ice-core analyses using microorganisms should be further developed because microorganisms growing on the glacier can be used as more than just seasonal markers for ice-core dating. Yoshimura and others (1997) showed that the biomass and species composition of snow algae growing on a Himalayan glacier clearly changed with altitude, reflecting changes in environmental conditions. Thus, the biomass and species composition of these microorganisms recorded in the ice core may be able to provide information on past environmental conditions on the glacier that affected their growth. However, more studies on their ecology and postdepositional processes are needed to use these microorganisms as a new environmental marker for ice-core analysis.

\section{CONCLUSIONS}

From the analysis of microorganisms and pollen in a $4.5 \mathrm{~m}$ pit and a $25.01 \mathrm{~m}$ ice core from Sofiyskiy glacier, we found that the ice-core and pit samples contained various snow algae, cyanobacteria, bacteria and fungi that grew on the glacier during the melt season. The snow algae and pollen showed clear seasonal cycles in the pit and the ice core, but seasonal cycles in $\delta^{18} \mathrm{O}$, chemical ions, other microorganisms and small snow algae $(<5 \mu \mathrm{m})$ were substantially disturbed by the heavy meltwater percolation and postdepositional decomposition. The seasonal cycles of snow algae and pollen in the ice core appear to be similar, allowing us to estimate the mean annual mass balance over 16 years (1985-99) to be $1.01 \mathrm{~m}$ w.e. The snow algae and pollen, therefore, could be a useful seasonal marker for icecore dating and reconstruction of past annual mass balance in lower-latitude and lower-altitude glaciers where isotopic and chemical signals are unreliable due to heavy meltwater percolation.

\section{ACKNOWLEDGEMENTS}

We acknowledge N.N. Mikhailov and I.A. Ponomarev for kindly supporting our field operations, S. Ohtani for advising on algae identification, and Y. lizuka, S. Matoba and M. Igarashi for chemical ion analysis. We also thank B. Duval and an anonymous reviewer for thoughtful comments which improved the manuscript. This research was supported by grants-in-aid from the International Scientific Research Program of the Ministry of Education, Culture, Sports, Science and Technology, Japan (No. 11208202 to K. Kamiyama of the National Institute of Polar Research; No. 16310004 to S. Kohshima; and Grants of the 21st Century COE (R12 and A10)); the research project 'Aeolian Dust Experiment on Climate Impact (ADEC)' funded by Special Coordination Funds for Promoting Science and Technology; and the Oasis Project (Historical Evolution of Adaptability in an Oasis Region to Water Resource Changes) promoted by the Research Institute of Humanity and Nature, Japan.

\section{REFERENCES}

Curl, H., Jr, J.H. Hardy and R. Ellermeier. 1972. Spectral absorption of solar radiation in Alpine snow fields. Ecology, 53, 1189-1194.
De Smedt, B. and F. Pattyn. 2003. Numerical modelling of historical front variations and dynamic response of Sofiyskiy glacier, Altai mountains, Russia. Ann. Glaciol., 37, 143-149.

Dyurgerov, M., Meier, M. and R. Armstrong, eds. 2002. Glacier mass balance and regime: data of measurements and analysis. Boulder, CO, University of Colorado. Institute of Arctic and Alpine Research. (INSTAAR Occasional Paper 55.)

Fujii, Y., F. Nishio and T. Kameda. 2000. Glaciological investigation on Sofiyskiy Glacier, Altai, Russian Federation. J. Jpn. Soc. Snow and Ice, Seppyo, 62(6), 549-556. [In Japanese with English summary.]

Fujii, Y. and 10 others. 2002. Outline of Japan-Russia joint glaciological research on Sofiyskiy Glacier, Russian Altai Mountains in 2000 and 2001. Bull. Glaciol. Res., 19, 53-58.

Fujita, K., N. Takeuchi, V. Aizen and S. Nikitin. 2004. Glaciological observations on the plateau of Belukha Glacier in the Altai Mountains, Russia from 2001 to 2003. Bull. Glaciol. Res., 21, $57-64$.

Hoham, R.W. and B. Duval. 2001. Microbial ecology of snow and freshwater ice with emphasis on snow algae. In Jones, H.G., J.W. Pomeroy, D.A. Walker and R.W. Hoham, eds. Snow ecology: an interdisciplinary examination of snow-covered ecosystems. Cambridge, Cambridge University Press, 168-228.

lizuka, Y., M. Igarashi, K. Watanabe, K. Kamiyama and O. Watanabe. 2000. Re-distribution of chemical compositions in the snowpack at the dome of Austfonna ice cap, Savlbard. J. Jpn. Soc. Snow and Ice, Seppyo, 62(3), 245-254. [In Japanese with English summary.]

Kameda, T. and 6 others. 2003. Seasonality of isotopic and chemical species and biomass burning signals remaining in wet snow in the accumulation area of Sofiyskiy Glacier, Russian Altai Mountains. Polar Meteorol. Glaciol., 17, 15-24.

Kameda, T. and 9 others. 2004. Stratigraphy and ice grains of a $25.3 \mathrm{~m}$ ice core from Sofiyskiy Glacier, Russian Altai Mountains. Bull. Glaciol. Res., 21, 65-69.

Kohshima, S. 1984. A novel cold-tolerant insect found in a Himalayan glacier. Nature, 310(5974), 225-227.

Kohshima, S. 1985. Patagonian glaciers as insect habitats. In Nakajima, C., ed. Glaciological studies in Patagonia Northern Icefield, 1983-1984. Nagoya, Japanese Society of Snow and Ice. Data Center for Glacier Research, 94-99.

Kohshima, S. 1987. Glacial biology and biotic communities. In Kawano, S., J.H. Connell and T. Hidaka, eds. Evolution and coadaptation in biotic communities. Kyoto, Kyoto University. Faculty of Science, 77-92.

Kohshima, S., Y. Yoshimura and N. Takeuchi. 2002. Glacier ecosystem and biological ice-core analysis. In Casassa, G., F.V. Sepúlveda and R. Sinclair, eds. The Patagonian ice fields: a unique natural laboratory for environmental and climate change studies. New York, Kluwer Academic/Plenum Publishers.

Kol, E. 1968. Kryobiologie, Biologie und Limnologie des Schnees und Eises. I: Kryovegetation. In Elstre, H.-J. and W. Ohle, eds. Die Binnengewasser. Stuttgart, E. Schweizerbartsche Verlagsbuchhandlung.

Kol, E. and J.A. Peterson. 1976. Cryobiology. In Hope, G.S., J.A. Peterson, U. Radok and I. Allison, eds. The equatorial glaciers of New Guinea: results of the 1971-1973 Australian Universities' expeditions to Irian Jaya. Rotterdam, A.A. Balkema, 81-91.

Luchik, Z.I. 1970. [Introduction to trees and shrubs in Altai territory]. Moscow, Lolos. [In Russian.]

Müller, T., W. Bleiss, C.D. Martin and S. Rogaschewski. 1998. Snow algae from north-west Svalbard: their identification, distribution, pigment and nutrient content. Polar Biol., 20(1), 14-32.

Müller, T., T. Leya and G. Fuhr. 2001. Persistent snow algal fields in Spitsbergen: field observations and a hypothesis about the annual cell circulation. Arct. Antarct. Alp. Res., 33(1), 42-51.

Nakazawa, F. and 8 others. 2004. Application of pollen analysis to dating of ice cores from lower-latitude glaciers. J. Geophys. Res., 109(F4), 4001. (10.1029/2004JF000125.) 
Oerlemans, J. 2005. Extracting a climate signal from 169 glacier records. Science, 308(5722), 675-677.

Pattyn, F. and 6 others. 2003. Ice dynamics and basal properties of Sofiyskiy glacier, Altai mountains, Russia, based on DGPS and radio-echo sounding surveys. Ann. Glaciol., 37, 286-292.

Richardson, S.G. and F.B. Salisbury. 1977. Plant response to the light penetrating snow. Ecology, 58, 1152-1158.

Segawa, T., K. Miyamoto, K. Ushida, K. Agata, N. Okada and S. Kohshima. 2005. Seasonal change in bacterial flora and biomass in mountain snow from the Tateyama Mountains, Japan, analyzed by $16 \mathrm{~S}$ rRNA gene sequencing and real-time PCR. Appl. Environ. Microb., 71, 123-130.

Shiraiwa, T. and 6 others. 2002. High net accumulation rates at Campo de Hielo Patagónico Sur, South America, revealed by analysis of a $45.97 \mathrm{~m}$ long ice core. Ann. Glaciol., 35, 84-90.

Suzuki, K., T. Kameda, M. Kohno, F. Nakazawa, J. Uetake and Y. Fujii. 2002. Meteorological observations on Sofiyskiy Glacier, Russian Altai Mountains. Polar Meteorol. Glaciol., 16, 140-148.

Takeuchi, N. 2001. The altitudinal distribution of snow algae on an Alaska glacier (Gulkana Glacier in the Alaska Range). Hydrol. Process., 15(18), 3447-3459.
Takeuchi, N. and S. Kohshima. 2004. A snow algal community on a Patagonian glacier, Tyndall glacier in the Southern Patagonia Icefield. Arct. Antarct. Alp. Res., 36(1), 91-98.

Thomas, W.H. and B. Duval. 1995. Sierra Nevada, California, U.S.A., snow algae: snow albedo changes, algal-bacterial interrelationships, and ultraviolet radiation effects. Arct. Alp. Res., 27(4), 389-399.

Thompson, L.G. and 9 others. 1989. Holocene-Late Pleistocene climatic ice core records from Qinghai-Tibetan Plateau. Science, 246(4929), 474-477.

Thompson, L.G. and 6 others. 1995. A 1000 year climatic ice-core record from the Guliya ice cap, China: its relationship to global climate variability. Ann. Glaciol., 21, 175-181.

Thompson, L.G., T. Yao, E. Mosley-Thompson, M.E. Davis, K.A. Henderson and P. Lin. 2000. A high-resolution millennial record of the south Asian monsoon from Himalayan ice cores. Science, 289(5486), 1916-1919.

Yoshimura, Y., S. Kohshima and S. Ohtani. 1997. A community of snow algae on a Himalayan glacier: change of algal biomass and community structure with altitude. Arct. Alp. Res., 29(1), 126-137.

Yoshimura, Y., S. Kohshima, N. Takeuchi, K. Seko and K. Fujita. 2000. Himalayan ice-core dating with snow algae. J. Glaciol., 46(153), 335-340. 